\title{
RESISTENSI NYAMUK Aedes aegypti TERHADAP CYPERMETHRIN DI KABUPATEN KLATEN, JAWA TENGAH
}

\author{
Nur Bebi Ulfah Irawati ${ }^{1 *}$, Novita Eka Putri ${ }^{2}$ \\ ${ }^{1}$ Program Studi Farmasi, STIKes Adila, Bandar Lampung, Indonesia \\ ${ }^{2}$ Program Studi Magister IImu Biomedik, Fakultas Kedokteran Kesehatan dan Keperawatan, \\ Universitas Gadjah Mada, Indonesia
}

\section{Artikel Info : \\ Received 13 April 2021 \\ Accepted 21 April 2021 \\ Available online 30 April \\ 2021 \\ Editor: Mey Ahyanti \\ Keyword : \\ Aedes aegypti, bioassay-test, cypermethrin, DHF, resistance}

Kata kunci :

Aedes aegypti, bioassay-test, cypermethrin, DBD, resistensi

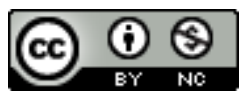

Ruwa Jurai: Jurnal

Kesehatan Lingkungan is licensed under a Creative Commons Attribution-NonCommercial 4.0 International License.

\begin{abstract}
Dengue Hemorrhagic Fever (DHF) is still a global health problem. The Aedes aegypti mosquito transmits $D H F$, so vector control is an effective strategy in disease prevention. One of the insecticides that have long been used in the Klaten Regency is cypermethrin. However, cases of DHF have been reported to have fluctuated over the past ten years. This study aims to determine the resistance of Ae.aegypti against cypermethrin. Ae.aegypti was obtained from three endemic sub-districts with the highest Ceper District cases, then colonized to the first generation (F1). The CDC bottle bioassay method was applied to determine mosquitoes' resistance status to cypermethrin at a dose of $10 \mu \mathrm{g} / \mathrm{ml}$. The results showed that cypermethrin resistance was found in all samples, from moderate to resistant levels. One sub-district sample showed resistance to cypermethrin (89\% mortality after 30 minutes). Two sub-district else showed moderate resistance status (97\% mortality after 30 minutes). The continuous use of the insecticide cypermethrin has had a resistance impact on the dengue vector. Community participation in eradicating breeding places is the main form of DHF control and insecticides with various active ingredients.
\end{abstract}

Penyakit Demam Berdarah Dengue (DBD) masih menjadi masalah kesehatan global. DBD ditularkan oleh nyamuk Aedes aegypti, sehingga kontrol vektor menjadi strategi efektif dalam penanggulangan penyakit. Salah satu insektisida yang telah lama digunakan di Kabupaten Klaten adalah cypermethrin. Namun kasus DBD dilaporkan masih berfluktuatif selama 10 tahun terakhir. Penelitian bertujuan mengetahui resistensi Ae. aegypti terhadap cypermethrin. Koleksi sampel telur Ae.aegypti diperoleh dari tiga kelurahan endemis dengan kasus tertinggi di Kecamatan Ceper, selanjutnya dikolonisasi hingga generasi pertama (F1). Metode CDC bottle bioassay diterapkan untuk menentukan status resistensi nyamuk terhadap cypermethrin pada dosis $10 \mu \mathrm{g} / \mathrm{ml}$. Hasil penelitian mendapatkan resistensi cypermethrin pada seluruh sampel, dari status sedang hingga resisten. Sampel dari satu kelurahan menunjukkan status resisten terhadap cypermethrin (mortalitas 89\% setelah 30 menit). Pada dua kelurahan lainnya menunjukkan status resistensi sedang (mortalitas $97 \%$ setelah 30 menit). Penggunaan insektisida cypermethrin secara terus-menerus telah memberikan dampak resistensi pada vektor DBD. Partisipasi masyarakat dalam pemberantasan sarang nyamuk merupakan bentuk pengendalian DBD yang utama, selain penggunaan insektisida dengan bahan aktif yang bervariasi.

\footnotetext{
${ }^{*}$ Corresponding author : Nur Bebi Ulfah Irawati

Jl. Soekarno Hatta No.110, Rajabasa, Kec. Rajabasa, Kota Bandar Lampung, Lampung 35144 Email: nurbebiulfah@gmail.com
}

\section{PENDAHULUAN}

Demam Berdarah Dengue (DBD) merupakan salah satu penyakit tular vektor yang disebabkan oleh virus dengue yang masuk dalam genus
Flavivirus, terdiri dari empat serotype (Kemenkes, 2011; Lloyd, 2003; World Health Organization, 1997). DBD ditransmisikan dari orang ke orang melalui vektor Aedes aegypti (Country Office for 
India, 2015; Yushananta, 2021; Yushananta, Setiawan, \& Tugiyono, 2020): Hingga saat ini masih menjadi masalah kesehatan masyarakat global, sebanyak 230 juta orang terinfeksi dan 21.000 berakhir dengan kematian (Yushananta, 2021). Di Indonesia kasus DBD pertama kali dilaporkan pada tahun 1968 dan hingga saat ini telah tersebar pada 433 Kabupaten/Kota, data terkait kasus DBD di Indonesia memiliki gambaran kejadian yang fluktuatif selama 10 tahun terakhir dengan Incidence Rate (IR) tertinggi terjadi pada tahun 2016 (Kemenkes, 2019).

Pengendalian vektor penyakit DBD dilakukan dengan berbagai cara, yaitu pengelolaan lingkungan secara fisik atau mekanis, biologi, dan kimiawi. Namun, diantara semuanya yang paling sering digunakan adalah dengan menggunakan agen kimiawi atau insektisida (Kemenkes, 2011; Lloyd, 2003; World Health Organization, 1997). Insektisida adalah bahan kimia yang dipergunakan untuk memberantas serangga, termasuk serangga penyebab penyakit pada manusia (Karauwan, Bernadus, \& Wahongan, 2017; Pradani, Ipa, Marina, \& Yuliasih, 2013). Insektisida pertama kali dikenal pada saat perang dunia kedua untuk membasmi hama (Karauwan et al., 2017).

Secara umum, insektisida sintetik yang sering digunakan adalah golongan pyrethroid yang bekerja mengganggu sistem syaraf, golongan organoklorin yang menyerang susunan saraf (neurotoxins), serta golongan organofosfat dan golongan karbamat sebagai racun kontak, racun perut dan juga racun pernapasan. Golongan insektisida pyrethroid yang paling sering digunakan untuk membasmi virus dengue (Karauwan et al., 2017; Susanti \& Boesri, 2012). Golongan pyrethroid yang banyak digunakan adalah cypermethrin, yaitu senyawa yang mengandung racun neurotoxin yang bekerja dengan cepat dalam tubuh serangga. Cypermethrin bekerja sebagai racun kontak dan perut yang sering digunakan untuk fogging (Hidayati, Nazni, Lee, \& Sofian-Azirun, 2011; Ikawati, Sunaryo, \& Widiastuti, 2015; Karauwan et al., 2017; Khazri et al., 2015; Koou, Chong, Vythilingam, Lee, \& Ng, 2014; Rodríguez, Hurtado, Severson, \& Bisset, 2014; Susanti \& Boesri, 2012). Pengendalian DBD yang diketahui efektif dilakukan dengan memutus rantai penularan vektor (Hidayati et al., 2011; Ikawati et al., 2015; Koou et al., 2014).

Penyakit DBD masih menjadi permasalahan serius di Provinsi Jawa Tengah, salah satunya adalah Kabupaten Klaten yang merupakan wilayah endemis DBD (Dinas Kesehatan Provinsi Jawa Tengah, 2019). Berdasarkan data Dinas Kesehatan Provinsi Jawa Tengah, jumlah kasus DBD pada tahun 2016 dilaporkan sebanyak 703 kasus ( $I R=60,4 \%$ per 100.000 penduduk), dan jumlah kematian sebanyak 22 orang (Cace Fatality Rate $(C F R)=3,1 \%)$. Tahun 2017, angka kejadian menurun dibandingkan tahun sebelumnya, menjadi $17,9 \%$ per 100.000 penduduk dan CFR 1,4\% (Dinas Kesehatan Provinsi Jawa Tengah, 2019).

Kecamatan Ceper merupakan satu dari total 26 kecamatan di Kabupaten Klaten dengan jumlah kasus DBD tertinggi selama tahun 20152017, dan merupakan salah satu daerah endemis DBD di Kabupaten Klaten. Pada tahun 20152017, terdapat tiga kelurahan endemis di wilayah Kecamatan Ceper, yaitu Kelurahan Ngawonggo, Kajen dan Meger (Dinkes Kabupaten Klaten, 2019). Hingga saat ini, strategi pengendalian vektor secara kimiawi masih dilakukan sebagai tindakan preventif dalam penanggulangan DBD, antara lain menggunakan bubuk abate (temephos) sebagai larvasida dan pyrethroid dengan bahan aktif cypermethrin untuk pengasapan (fogging).

Penggunaan insektisida cypermethrin telah dilakukan sejak 10 tahun terakhir secara terusmenerus. Menurut Kemenkes, penggunaan pestisida dengan bahan aktif yang sama secara terus menerus dan dosis yang tidak tepat dapat menurunkan sensitivitas senyawa insektisida terhadap populasi vektor (Kemenkes, 2012). Penurunan sensitivitas menyebabkan resistensi vektor terhadap senyawa insektisida, sehingga menjadi kendala dalam pengendalian vektor DBD. Resistensi akan menimbulkan masalah karena serangga yang telah resisten akan menurunkan keturunan resisten, sehingga akan meningkatkan proporsi vektor resisten dalam populasi (Ikawati et al., 2015).

Terdapat dua mekanisme utama resistensi insektisida yaitu 1) resistensi metabolisme berupa peningkatan enzim detoksifikasi 
sehingga senyawa insektisida dinetralisasi sebelum mencapai target site; 2) modifikasi target site senyawa insektisida atau knockdown resistance $(k d r)$, apabila terdapat mutasi pada gen yang menyandi protein target molekul insektisida (Hemingway, Hawkes, McCarroll, \& Ranson, 2004). Penelitian bertujuan mengetahui resistensi cypermethrin di tiga wilayah endemis DBD di Kecamatan Ceper, yaitu Kelurahan Ngawonggo, Kajen dan Meger.

\section{METODE}

1. Rancangan dan subjek penelitian

Penelitian merupakan

penelitian observasional untuk mengetahui resistensi nyamuk Ae.aegypti terhadap cypermethrin. Subjek penelitian adalah nyamuk Ae.aegypti betina generasi F-1 yang dikembangkan dari tiga lokasi penelitian yaitu Kelurahan Ngawonggo, Kajen dan Meger.

\section{Koleksi telur dan kolonisasi Ae. aegypti}

Penelitian diawali dengan mengumpulkan telur nyamuk Ae.aegypti menggunakan ovitrap. Sebanyak 353 ovitrap diletakkan pada 241 rumah. Penentuan lokasi rumah dilakukan mengacu pada ketetapan FUNASA (Da Silva Soares et al., 2003), dan WHO (World Health Organization, 2011) dengan memperhatikan jumlah bangunan dan House Index (HI). Kriteria rumah tempat peletakan ovitrap antara lain, rumah dilaporkan sebagai titik kasus DBD pada tiga tahun terakhir (2015-2017) dan rumah yang berada pada radius $100 \mathrm{~m}$ dari titik kasus tersebut.

Ovitrap adalah gelas plastik yang dicat berwarna hitam, berisi $2 / 3$ air bersih dan dipasangkan kertas saring untuk oviposisi nyamuk Ae.aegypti, setiap ovitrap diberi label dan nomor sesuai dengan lokasi kelurahan penelitian. Ovitrap diletakkan di bagian dalam dan luar rumah yang sekiranya berpotensi sebagai tempat bertelur nyamuk, selama 3-7 hari. Ovitrap yang telah diambil kemudian dipisahkan dengan kertas saring, selanjutnya kertas saring dikeringkan pada suhu ruangan dan pengambilan telur yang melekat pada kertas saring.

Penelitian dilanjutkan dengan kolonisasi (rearing) dari telur hingga menjadi nyamuk dewasa di Laboratorium Parasitologi FKKMK UGM. Pemisahan larva Ae.aegypti dilakukan pada instar II. Pengujian menggunakan nyamuk betina berumur 3-5 hari dan kenyang larutan gula $10 \%$.

\section{Uji bioassay nyamuk Ae. aegypti}

Uji resistensi nyamuk Ae.aegypti terhadap cypermethrin menggunakan dosis diagnostik 10 $\mu \mathrm{g} / \mathrm{ml}$, dengan metode $C D C$ bottle bioassay (CDC, 2012). Kematian nyamuk (mortalitas) dihitung setelah 30 menit pemaparan cypermethrin $10 \mu \mathrm{g} / \mathrm{ml}$. Kontrol adalah nyamuk Ae.aegypti yang dibiakkan dari Laboratorium Parasitologi FKKMK UGM. Jika mortalitas pada kelompok kontrol $>10 \%$, maka pengujian harus diulang. Jika mortalitas 3-10\%, dilakukan perhitungan menggunakan formula Abbot. Mortalitas dihitung dengan formula:

$$
\mathrm{M}=\frac{M 1}{M 0} \times 100 \%
$$

$M=$ Persentase kematian namyuk (Mortalitas)

$\mathrm{M}_{1}=$ Jumlah kematian nyamuk uji

$\mathrm{M}_{0}=$ Jumlah nyamuk yang diuji

Status resistensi nyamuk Ae.aegypti terhadap insektisida cypermethrin dikelompokkan menjadi tiga kategori, yaitu rentan $(\geq 98 \%)$, resistan sedang $(90 \%-97 \%)$ dan resistan $(<90 \%$ (Health Organization, 2016). Pengujian dilakukan dalam empat kali pengulangan.

\section{HASIL}

Status resistensi nyamuk Ae.aegypti terhadap insektisida cypermethrin dosis $10 \mu \mathrm{gg} / \mathrm{ml}$ didapatkan berdasarkan mortalitas selama waktu diagnostik 30 menit (Tabel 1). Pada kelompok kontrol, mortalitas mencapai $100 \%$, sehingga tidak dilakukan koreksi dengan formula Abbot.

Hasil penelitian mendapatkan (Tabel 1) bahwa seluruh nyamuk menunjukkan resistensi terhadap cypermethrin. Sampel dari dua kelurahan, yaitu Kelurahan Ngawonggo dan Kajen, menunjukkan status resistensi sedang dengan mortalitas sebesar $97 \%$. Sedangkan dari Kelurahan Meger, menunjukkan status resisten, dengan mortalitas $89 \%$. 


\section{PEMBAHASAN}

Hasil penelitian mendapatkan status resisten pada daerah dengan kasus rendah, sedangkan pada daerah dengan jumlah kasus tinggi dan sedang menunjukkan status resistensi sedang. Secara umum, terlihat anomali data. Namun data penelitian yang diperoleh, sesuai dengan Dinkes Kabupaten Klaten, menyatakan bahwa frekuensi tertinggi fogging dalam 10 tahun terakhir dilakukan di Kelurahan Meger, disusul dengan Kelurahan Kajen dan Ngawonggo.

Resisensi insektisida terjadi akibat penggunaan secara terus menerus dalam waktu lama dan dosis yang tidak tepat (Ikawati et al., 2015; Karauwan et al., 2017; Kemenkes, 2012; Tasane, 2015). Karakteristik wilayah studi juga menunjukkan perbedaan, walaupun secara geografis berdekatan. Kelurahan Ngawonggo dan Kelurahan Meger merupakan daerah urban dengan populasi penduduk yang padat. Sedangkan Kelurahan Kajen merupakan daerah rural yang didominasi area persawahan dan hampir setiap rumah memiliki halaman yang cukup luas. Pengelolaan halaman yang kurang baik, menyebabkan terbentuknya tempat perindukan vektor. Resistensi vektor terhadap insektisida dipengaruhi oleh kondisi lingkungan (Nkya, Akhouayri, Kisinza, \& David, 2013). Hasil ovitrap di Kelurahan Kajen menunjukkan dominan vektor di luar rumah. Menurut Ikawati, resistensi dapat bersifat terlokalisir terutama apabila pada tempat lain tidak ada aplikasi pengendalian nyamuk yang sama, atau tidak ada perpindahan nyamuk Ae.aegypti resisten yang dapat menjadi faktor penyebab diturunkannya nyamuk resisten (Ikawati et al., 2015).

Tabel 1. Hasil uji bioassay nyamuk Ae. aegypti terhadap cypermethrin pada dosis $10 \mu \mathrm{g} / \mathrm{ml}$

\begin{tabular}{lllll}
\hline Lokasi (Kelurahan) & Karakteristik & Generasi & Mortalitas & Kategori \\
\hline Ngawonggo & Jumlah kasus tinggi & F1 & $97 \%$ & Resisten sedang \\
Kajen & Jumlah kasus sedang & F1 & $97 \%$ & Resisten sedang \\
Meger & Jumlah kasus rendah & F1 & $89 \%$ & Resisten \\
Kontrol & - & F2 & $100 \%$ & Rentan \\
\hline
\end{tabular}

Hasil penelitian sesuai dengan Ikawati et al, yang menyatakan telah terjadi resistensi cypermethrin 0,05\% pada hampir semua sampel Ae.aegypti yang diambil di sembilan kabupaten di Jawa Tengah. Mortalitas nyamuk antara 10,00\%-63,33\%, kecuali sampel dari Kabupaten Banjarnegara yang memiliki toleran (Ikawati et al., 2015). Pada tahun 2011, resistensi Ae. aegypti terhadap cypermethrin 0,05\% juga dilaporkan terjadi di delapan wilayah di Jawa Tengah, yaitu di Jepara, Blora, Kota Semarang, Kota Salatiga, Kota Surakarta, Kota Tegal, Kota Magelang, Kota Purwokerto (Widiarti et al., 2011), dan Kota Cimahi (Pradani, Ipa, Marina, \& Yuliasih, 2011).

Resisensi insektisida terjadi akibat penggunaan secara terus menerus dalam waktu lama dan dosis yang tidak tepat (Ikawati et al., 2015; Karauwan et al., 2017; Kemenkes, 2012; Tasane, 2015). Resistensi akan menimbulkan masalah karena nyamuk resisten akan menurunkan keturunan yang resisten, sehingga akan meningkatkan proporsi vektor resisten dalam populasi (Ikawati et al., 2015).
Perpindahan nyamuk resisten ke daerah baru karena mengikuti mobilitas orang dan barang, juga diduga sebagai penyebab resistensi. Nyamuk Ae.aegypti resisten akan kawin dengan Ae.aegypti susceptible yang akhirnya menurunkan Ae.aegypti yang resisten (Koou et al., 2014). Penelitian di Cuba menunjukkan bahwa resistensi terhadap pada populasi Ae.aegypti diturunkan dari satu generasi ke generasi berikutnya (Rodríguez et al., 2014). Demikian pula laporan dari Malaysia, Ae.aegypti resisten malathion yang dikembang-biakkan di laboratorium sampai generasi ke-45, menunjukkan peningkatan resistensi sebesar 3,24 kali dibandingkan generasi ke-0 (Hidayati et al., 2011).

Perbedaan status resistensi antar wilayah penelitian juga berkaitan dengan kebiasaan masyarakat menggunakan insektisida dalam membasmi serangga dan nyamuk. Sebagian besar insektisida yang dijual bebas di pasaran menggunakan senyawa golongan pyrethroid dengan bahan aktif alterin dan cypermethrin 
(Karauwan et al., 2017; Riyadi \& Satoto, 2017). Keaktifan Juru Pemantau Jentik (Jumantik) dalam memonitor tempat perindukan vektor, serta pengetahuan dan kesadaran masyarakat melakukan pemberantasan sarang nyamuk (PSN), juga ikut menjadi faktor penentu resistensi. Semakin baik perilaku PSN masyarakat di suatu wilayah, maka semakin rendah pula vektor DBD ditemukan (Parulian Manalu \& Munif, 2016; Wigati \& Susanti, 2013).

Mekanisme resistensi pada vektor disebabkan oleh faktor operasional dan faktor biologis (Georghiou \& Saito, 1983). Faktor operasional meliputi jenis insektisida, teknik aplikasi, dosis dan frekuensi aplikasi (Musfirah, 2017). Program pengendalian DBD yang dilakukan Dinas Kesehatan Kabupaten Klaten dengan cara pengasapan (fogging) menggunakan cypermethrin selama 10 tahun terus-menerus. $\mathrm{Di}$ sisi lain, penggunaan insektisida di rumah tangga ikut memicu terjadinya resistensi. Menurut Riyadi dan Satoto, penggunaan insektisida di rumah tangga dengan dosis yang tidak tepat dapat memicu resistensi (Riyadi \& Satoto, 2017).

Faktor biologis adalah kemampuan alami nyamuk Ae.aegypti dalam beradaptasi terhadap lingkungan. Resistensi terhadap insektisida merupakan salah satu bentuk adaptasi terhadap tekanan selektif sebagai bentuk proses evolusi yang diturunkan secara generatif (Ahmad, 2011; Hemingway et al., 2004). Adaptasi dapat berupa peningkatan enzim detoksifikasi atau modifikasi target site (Hemingway et al., 2004). Meningkatnya jumlah populasi nyamuk resistan, menunjukkan terjadinya peningkatan resistensi terhadap pestisida yang digunakan (Kemenkes, 2012).

\section{SIMPULAN}

Penelitian mendapatkan resistensi nyamuk Ae.aegypti terhadap cypermethrin pada seluruh daerah penelitian. Penggunaan pestisida yang sama secara terus-menerus dalam waktu yang lama, diduga sebagai penyebab resistensi. Meningkatkan kesadaran dan peran serta masyarakat dalam PSN menjadi bentuk pengendalian penyakit DBD yang utama. Otoritas kesehatan diharapkan menggunakan pestisida dengan bahan aktif yang bervariasi dalam pembasmian vektor.

\section{UCAPAN TERIMAKASIH}

Terima kasih disampaikan kepada Dinas Kesehatan Kabupaten Klaten, Laboratorium Parasitologi FKKMK Universitas Gadjah Mada, serta seluruh pihak yang telah membantu jalannya penelitian.

\section{DAFTAR PUSTAKA}

Ahmad, I. (2011). Adaptasi serangga dan dampaknya terhadap kehidupan manusia. Pidato Guru Besar Institut Teknologi Bandung, pp. 0-46.

CDC. (2012). Guideline for Evaluating Insecticide Resistance in Vectors Using the CDC Bottle Bioassay (1st ed.; W. G. Brogdon \& Adeline Chan, Eds.). Retrieved from http://www.cdc.gov/malaria.

Country Office for India, W. H. O. (2015). National guidelines for clinical management of dengue fever. Retrieved from https://apps.who.int/iris/handle/10665/20889 3

Da Silva Soares, S., Valle, D., Ramos, R. P., Ribeiro Galardo, A. K., Da-Cinha, M. P., Braga, I. A., ... Da Silva Junior, R. C. (2003). Resistance of Aedes aegypti to organophosphates in several municipalities in the State of Rio de Janeiro and Espirito Santo, Brazil. The American Journal of Tropical Medicine and Hygiene, 68(3), 329-333. https://doi.org/10.4269/ajtmh.2003.68.329

Dinas Kesehatan Provinsi Jawa Tengah. (2019). Profil Kesehatan Provinsi Jawa Tengah Tahun 2018 (D. K. P. J. Tengah, Ed.). Retrieved from http://dinkesjatengprov.go.id/v2018/dokume n/profil_2018/mobile/index.html

Dinkes Kabupaten Klaten. (2019). PROFIL KESEHATAN TAHUN 2018. Klaten.

Georghiou, G. P., \& Saito, T. (Eds.). (1983). Pest Resistance to Pesticides. https://doi.org/10.1007/978-1-4684-4466-7

Health Organization, W. (2016). Test procedures for insecticide resistance monitoring in malaria vector mosquitoes Global Malaria Programme (2nd ed.). Geneva 27, Switzerland.

Hemingway, J., Hawkes, N. J., McCarroll, L., \& Ranson, H. (2004). The molecular basis of insecticide resistance in mosquitoes. Insect Biochemistry and Molecular Biology, 34(7), 653-665. https://doi.org/10.1016/j.ibmb.2004.03.018

Hidayati, H., Nazni, W. A., Lee, H. L., \& SofianAzirun, M. (2011). Insecticide resistance 
development in Aedes aegypti upon selection pressure with malathion. Tropical Biomedicine, 28(2), 425-437. Retrieved from http://www.ncbi.nlm.nih.gov/pubmed/220417 65

Ikawati, B., Sunaryo, S., \& Widiastuti, D. (2015). Peta status kerentanan Aedes aegypti (Linn.) terhadap insektisida cypermethrin dan malathion di Jawa Tengah. ASPIRATOR Journal of Vector-Borne Disease Studies, 7(1). https://doi.org/10.22435/aspirator.v7i1.3722.2 3-28

Karauwan, I. G., Bernadus, J. B. B., \& Wahongan, G. P. (2017). Uji Resistensi Nyamuk Aedes Aegypty Dewasa Terhadap Cypermethrin Di Daerah Pasar Tua Bitung 2016. Jurnal Kedokteran Klinik, 1(3), 42-46. https://doi.org/10.1109/E3S.2015.7336790

Kemenkes. (2011). Modul pengendalian demam berdarah dengue. In Jakarta. Available from.

Kemenkes. (2012). Pedoman Pengendalian Insektisida (Pestisida) Dalam Pengendalian Vektor. Jakarta.

Kemenkes. (2019). Profil Kesehatan Indonesia 2018. In Ministery of Health. Retrieved from https://pusdatin.kemkes.go.id/resources/dow nload/pusdatin/profil-kesehatanindonesia/PROFIL_KESEHATAN_2018_1.pdf

Khazri, A., Sellami, B., Dellali, M., Corcellas, C., Eljarrat, E., Barceló, D., \& Mahmoudi, E. (2015). Acute toxicity of cypermethrin on the freshwater mussel Unio gibbus. Ecotoxicology and Environmental Safety, 115, 62-66. https://doi.org/10.1016/j.ecoenv.2015.01.028

Koou, S.-Y., Chong, C.-S., Vythilingam, I., Lee, C.-Y., $\&$ Ng, L.-C. (2014). Insecticide resistance and its underlying mechanisms in field populations of Aedes aegypti adults (Diptera: Culicidae) in Singapore. Parasites \& Vectors, 7(1), 471. https://doi.org/10.1186/s13071014-0471-0

Lloyd, L. S. (2003). Best practices for dengue prevention and control in the Americas. Washington DC Camp Dresser and McKee International Environmental Health ....

Musfirah, M. (2017). Pengendalian Kimia dan Resistensi Vektor Anopheles Dewasa pada Kawasan Endemis Malaria di Dunia. Kes Mas: Jurnal Fakultas Kesehatan Masyarakat Universitas Ahmad Daulan, 11(1), 46-51. https://doi.org/10.12928/kesmas.v11i1.5855

Nkya, T. E., Akhouayri, l., Kisinza, W., \& David, J.-P. (2013). Impact of environment on mosquito response to pyrethroid insecticides: Facts, evidences and prospects. Insect Biochemistry and Molecular Biology, 43(4), 407-416. https://doi.org/10.1016/j.ibmb.2012.10.006 Parulian Manalu, H. S., \& Munif, A. (2016). Pengetahuan dan Perilaku Masyarakat dalam Pencegahan Demam Berdarah Dengue di Provinsi Jawa Barat dan Kalimantan Barat. ASPIRATOR - Journal of Vector-Borne Disease Studies, 8(2), 69-76.

https://doi.org/10.22435/aspirator.v8i2.4159.6 9-76

Pradani, F. Y., Ipa, M., Marina, R., \& Yuliasih, Y. (2011). Status Resistensi Aedest aegypti dengan Metode Susceptibility di Kota Cimahi terhadap Cypermethrin. Aspirator - Journal of Vector Borne Diseases StudieA \& A (Ciamis), 3(1).

Pradani, F. Y., Ipa, M., Marina, R., \& Yuliasih, Y. (2013). Status Resistensi Aedes aegypti dengan Metode Susceptibility di Kota Cimahi terhadap Cypermethrin. Aspirator Journal of Vector-Borne Diseases, 3(1), 18-24.

https://doi.org/10.22435/aspirator.v3i1.2955.

Riyadi, S., \& Satoto, T. B. T. (2017). Hubungan Perilaku Penggunaan Insektisida dengan Status Kerentanan Nyamuk Aedes aegypti di Daerah Endemis Kabupaten Purbalingga. Berita Kedokteran Masyarakat, 33(10), 459. https://doi.org/10.22146/bkm.25941

Rodríguez, M. M., Hurtado, D., Severson, D. W., \& Bisset, J. A. (2014). Inheritance of Resistance to Deltamethrin in Aedes aegypti (Diptera: Culicidae) From Cuba. Journal of Medical Entomology, 51(6), 1213-1219. https://doi.org/10.1603/ME13237

Susanti, L., \& Boesri, H. (2012). Insektisida Sipermethrin $100 \mathrm{G} / \mathrm{L}$ Terhadap Nyamuk Dengan Metode Pengasapan. KESMAS Jurnal Kesehatan Masyarakat, 7(2), 156-163. https://doi.org/10.15294/kemas.v7i2.2812

Tasane, I. (2015). Uji Resistensi Insektisida Malathion 0,8\% Terhadap Nyamuk Aedes Aegypti Di Wilayah Fogging Kantor Kesehatan Pelabuhan Kelas II Ambon. Jurnal Kesehatan Masyarakat Universitas Diponegoro, 3(3).

Widiarti, Heriyanto, B., Boewono, D. T., Widyastuti, U., Mujino, Lasmiati, \& Yuliadi. (2011). PETA RESISTEWST VEKTOR DEMAM BERDAMH DENGUE. Buletin Penelitian Kesehatan, 39(4), 176-189. 
Wigati, R. A., \& Susanti, L. (2013). Hubungan Karakteristik, Pengetahuan, Dan Sikap, Dengan Perilaku Masyarakat Dalam Penggunaan Anti Nyamuk Di Kelurahan Kutowinangun. Bulletin of Health Research, 40(3 Sep), 129-138. https://doi.org/10.22435/bpk.v40i3Sep.2895.1 29-138

World Health Organization. (1997). Dengue Haemorrhagic Fever Diagnosis, Treatment, prevention and Control (second Edi).

World Health Organization. (2011). Comprehensive Guideline for Prevention and Control of Dengue and Dengue Haemorrhagic Fever. Revised and expanded edition. Retrieved from https://apps.who.int/iris/handle/10665/20489 4
Yushananta, P. (2021). Dengue Hemorrhagic Fever and Its Correlation with The Weather Factor In Bandar Lampung City City: Study From 2009-2018. Jurnal Aisyah: Jurnal Ilmu Kesehatan, 6(1), 117-126.

Yushananta, P., Setiawan, A., \& Tugiyono, T. (2020). Variasi Iklim dan Dinamika Kasus DBD di Indonesia: Systematic Review. Jurnal Kesehatan, 11(2), 294.

https://doi.org/10.26630/jk.v11i2.1696 